RESEARCH ARTICLE

Aysima Bulca Acar ${ }^{1}$

Remziye Nur Eke ${ }^{1}$

D Mehmet Ozen ${ }^{1}$

${ }^{1}$ University of Health Sciences Antalya Training and Research Hospital, The Clinic of Family Medicine Antalya, Turkey

Corresponding Author:

Aysima Bulca Acar

University of Health Sciences

Antalya Training and Research Hospital, The Clinic of Family Medicine Antalya, Turkey mail: aysimabulca@gmail.com Phone: +90 5544751754

Received: 15.02 .2021

Acceptance: 12.07.2021

DOI: $10.18521 / \mathrm{ktd} .880762$

Konuralp Medical Journal e-ISSN1309-3878

konuralptipdergi@duzce.edu.tr konuralptipdergisi@gmail.com www.konuralptipdergi.duzce.edu.tr

\section{An Analysis of the Attitudes of Family Physicians towards the COVID-19 Vaccine \\ ABSTRACT}

Objective: This study has aimed to reveal the opinions of family physicians on the COVID-19 vaccine.

Methods: The data collection forms prepared for this cross-sectional study were converted into an online questionnaire form and sent to the physicians working as family physicians in different provinces of Turkey between December 2020 - January 2021 via emails (GoogleGroups) and communication groups (Facebook, WhatsApp, etc.). The responses of 494 family physicians in Turkey, who were accessible through this method and volunteered to participate in the study, were recorded to be analysed.

Results: Of the 494 family physicians in our study, $6.3 \%(n=31)$ appeared to have no intention of getting vaccinated against the COVID-19, whereas $13.2 \% \quad(n=65)$ were undecided. The opinion towards which the participants in our study had the highest positive attitude was related to the necessity to provide everyone with the COVID-19 vaccine', while the most obvious negative attitude was related to the view that the efficacy of the vaccine has not yet been tested sufficiently.

Conclusions: Although a significant majority of family physicians have a positive attitude towards the need for administering the COVID-19 vaccine, more than half have expressed a negative or indecisive attitude towards relying on the statements made about the vaccine and its efficacy, which is said to have been adequately tested. For the desired levels can be reached in terms of vaccination rates, it is necessary to inform family physicians about the efficacy and benefits of the vaccine and to convey this information to individuals through family physicians.

Keywords: Family Medicine, Vaccination, COVID-19.

\section{Aile Hekimlerinin COVID-19 Așısına Yönelik Tutumlarının Değerlendirilmesi \\ ÖZET}

Amaç: $\mathrm{Bu}$ çalışmada aile hekimlerinin COVID-19 aşısına yönelik düşüncelerinin incelenmesi amaçlanmıştır.

Gereç ve Yöntem: Kesitsel tipteki bu çalışma için hazırlanan veri toplama formları online anket formuna dönüştürülerek Aralık 2020 - Ocak 2021 tarihleri arasında Türkiye'nin farklı illerinde aile hekimi olarak çalışan hekimlere e-posta (GoogleGroups) ve iletişim grupları (Facebook, WhatsApp vb.) aracılığı ile iletildi. Bu yöntemle ulaşılan ve çalışmaya katılmaya gönüllü olan Türkiye'deki 494 aile hekiminin yanıtları analiz edilmek üzere kayıt altına alındı.

Bulgular: Çalışmamızda yer alan 494 aile hekiminin \%6,3'ünün $(n=31)$ aşı olmayı düşünmediği, \%13,2'sinin $(n=65)$ ise aşı olmak konusunda kararsız olduğu belirlendi. Çalışmadaki katılımcıların en yüksek düzeyde olumlu tutum içerisinde olduğu görüş herkese COVID-19 aşısı uygulanması gerektiği iken; en belirgin olumsuz tutum ise aşının etkinliğinin yeterince test edilmediği olarak belirlendi.

Sonuç: Aile hekimlerinin önemli bir çoğunluğu COVID-19 aşısının topluma uygulanması konusunda olumlu bir tutuma sahipken, yarıdan fazlası aşı ve etkinliği hakkında yapılan açıklamalara güvenme konusunda olumsuz veya kararsız bir tutum sergilemiştir. Aşılama oranlarının istenilen seviyelere ulaşabilmesi için aile hekimlerinin ve aile hekimleri aracılığı ile toplumun aşının güvenilirliğine ve etkililiğine dair daha fazla bilgilendirilmesine ihtiyaç vardır.

Anahtar Kelimeler: Aile Hekimliği, Aşılama, COVID-19. 


\section{INTRODUCTION}

The COVID-19 virus is rapidly transmitted from person to person and can result in massive destructive consequences. The pandemic caused by the virus has, therefore, been declared as a public health problem by the World Health Organization (WHO) (1).

Since the beginning of the pandemic, scientists have been trying to develop treatments with intensive efforts in order to alleviate the evident upsurge in the number of cases and prevent negative clinical consequences around the world. Although many studies exist on the possible treatment of the virus, the consensus among experts is that only an effective COVID-19 vaccine will end the pandemic (2). For this purpose, Russia became the first country in the world to approve a vaccine developed against COVID-19 on August 11, 2020, and named it Sputnik V (3). According to the official statement of the WHO, there are 105 COVID-19 vaccine candidates in clinical development (4). A number of treatments that have been attempted in a short time with intense efforts have, unfortunately, brought some uncertainties. Despite the seemingly high efficacy of the vaccines, developed through Phase 3 trials with relatively short follow-up periods due to the race against time, it is also widely accepted that more reliable information is needed about longer-term safety and duration of vaccine protection (5).

A major concern is the administration of a weakly effective vaccine, which may lead to an erroneous interpretation among the authorities that there is a significant reduction in risk, and may negatively affect compliance with the control of the pandemic (6). Vaccination is a measure within the scope of primary protection as a preventive health service and the protective effect of vaccination depends on epidemiological criteria such as the efficacy and effectiveness of the vaccine, the effects of the vaccine program, the infectious effects of the vaccine, and the number of people needed to vaccinate (7).

In the management of the pandemic, family physicians, who are the backbone of preventive health services, are thought to have responsibilities in various areas, ranging from triage, treatment, follow-up, efficient use of resources, and providing cost-effective care (8). In Turkey, the source cases and their contacts have been identified, and the isolation of the cases and the quarantine of the contact persons have been ensured thanks to the strictly applied contract tracing under the leadership of family physicians.

In line with the latest developments in Turkey, family physicians has active duties and responsibilities in the vaccination process too.

It is believed that the COVID-19-vaccinerelated attitudes and behaviours of family physicians, who deliver protective and preventive health care services to the public and are in close contact with individuals in the community, will be influential in the vaccination rates in the society. This study has aimed to reveal the opinions of family physicians on the COVID-19 vaccine.

\section{MATERIAL AND METHODS}

Sample Groups: The population of this cross-sectional survey study consisted of healthcare professionals working as family physicians in Turkey.

While calculating the sample size, the information that the number of family physicians in Turkey is 24,428 was used (9). It is aimed to reach 378 people with a $95 \%$ confidence interval and a $5 \%$ margin of error using the formula for Sample Size for Finite Universe $\left(n=X^{2} N P(1-P) \div\right.$ $\mathrm{d}^{2}(\mathrm{~N}-1)+\mathrm{X}^{2} \mathrm{P}(1-\mathrm{P})$.

The data collection period started on 22 December 2020 with a group of 50 people, the majority of whom were physicians working in the Family Medicine Clinic in University of Health Sciences Antalya Training and Research Hospital. First of all, data collection forms were sent to physicians as online questionnaires via e-mail (GoogleGroups) and communication groups (Facebook, WhatsApp). After being asked sociodemographic and descriptive questions, the physicians were administered the 'COVID-19 Vaccination Attitude Scale', consisting of nine questions and two sub-dimensions (negative and positive attitude) which was developed in Turkey by Geniş et al. (10).

The data collection forms containing the scale were delivered to other family physicians in the form of an online questionnaire via e-mail and communication groups by snowball sampling. After subtracting the answers of 2 participants who declined to participate in the study, 15 participants whose questionnaires were received back more than once, and 2 participants who gave inappropriate answers (such as having more years of professional experience than their age), the answers of the remaining 494 family physicians from 53 different provinces were recorded and the data collection period ended on 08.01.2021, when Turkey had not yet started mass vaccination.

Measurement Tools

Sociodemographic Data Form: The present study includes a data form prepared by the researchers in such a way as to contain age, gender, marital status, and other sociodemographic and clinical characteristics associated with the COVID19 pandemic.

COVID-19 Vaccination Attitude Scale: Developed by Geniş et al., consisting of nine questions and two sub-dimensions (negative and positive attitude) (10). The levels of expressions in the scale were presented as 'Definitely Disagree' 1 , 'Disagree' 2, 'Undecided' 3, 'Agree' 4, and 'Strongly Agree' 5; the items in the negative attitude 
sub-dimensions were scored in reverse order as follows: $(1 \rightarrow 5,2 \rightarrow 4,3 \rightarrow 3,4 \rightarrow 2,5 \rightarrow 1)$. A mean value between 1-5 was obtained by dividing the score obtained by the sum of the item scores in the scale sub-dimension by the number of items in that sub-dimension. If that mean value was for the positive attitude sub-dimension and high, the attitude towards the vaccine was deemed positive, if, on the contrary, it was for the negative attitude sub-dimension and high, the participants were considered to hold less negative attitudes towards the vaccine.

Prior to the study, the necessary permission was first obtained to use the scale, and approval was obtained from the Scientific Research Platform of the Ministry of Health and the University of Health Clinical Research Ethics Committee with the decision number 20/13, dated 22.12.2020. The study was conducted in accordance with the Declaration of Helsinki.

Statistical Assessment: The data obtained in the study were analysed using IBM SPSS 23.0 software (IBM Corp., Armonk, NY). Descriptive statistics were presented with $\mathrm{n}(\%)$ and mean \pm standard deviation and median (min-max) values. Fisher's Exact test was used to examine the relationships between categorical variables, and Bonferroni correction was applied in paired comparisons. Shapiro Wilks test was used to assess the assumption of normality. Mann-Whitney $U$ test and Student's t test were used for analysis of nonnormally and normally distributed numerical data, respectively. Kruskal Wallis test was used for comparison of non-parametric variables among groups and Bonferroni-Dunn test was used as a post-hoc test for significant cases. One-Way ANOVA was used for comparison of parametric variables between groups and Tukey HSD test was used as a post-hoc test for significant cases. Spearman's rank correlation test was used for relationships between ordinal variables or continuous variables, not conforming to normal distribution, while Pearson's correlation test was used for variables conforming to normal distribution. Cronbach's alpha reliability coefficient was calculated in the analysis of internal consistency of the scales. A $\mathrm{p}$ value less than 0.05 was considered statistically significant.

\section{RESULTS}

Of the 494 family physicians participating in our study, $55.7 \%$ were women, while $44.3 \%$ were men, with the average age of $37.1 \pm 9.6$ (25-63). Sciences Antalya Training and Research Hospital

The majority of the participants $(55.7 \%)$ work in Family Health Centres (FHC) (Table 1).

According to the data based on whether the participants were infected with COVID-19 virus and documented accordingly, 427 (86.4\%) physicians- the majority of the participants- were found not to have been infected with the COVID-19 virus. On the other hand, 31 (6.3\%) physicians appeared that they had no intention of being vaccinated against the COVID-19 virus when asked about their relevant opinion (Table 2).

Table 1. Sociodemographic characteristics of the participants

\begin{tabular}{|c|c|}
\hline Variables & n:494 \\
\hline Age (years) & $37.1 \pm 9.6(25-63)$ \\
\hline $25-34$ & $249(50.4 \%)$ \\
\hline $35-44$ & $115(23.3 \%)$ \\
\hline $45-54$ & $105(21.3 \%)$ \\
\hline $55-64$ & $25(5.1 \%)$ \\
\hline \multicolumn{2}{|l|}{ Gender } \\
\hline Female & $275(55.7 \%)$ \\
\hline Male & $219(44.3 \%)$ \\
\hline \multicolumn{2}{|l|}{ Title } \\
\hline Specialist doctor & $118(23.9 \%)$ \\
\hline Family medicine assistant & $146(29.6 \%)$ \\
\hline $\begin{array}{l}\text { Non-tenured family physician with } \\
\text { ongoing training for specialty }\end{array}$ & $54(10.9 \%)$ \\
\hline Academic & $20(4 \%)$ \\
\hline Non-tenured family physician & $156(31.6 \%)$ \\
\hline \multicolumn{2}{|l|}{ Place of work } \\
\hline Training and research hospital & $85(17.2 \%)$ \\
\hline Family health centre & $275(55.7 \%)$ \\
\hline University hospital & $82(16.6 \%)$ \\
\hline State hospital & $25(5.1 \%)$ \\
\hline $\begin{array}{l}\text { Provincial/District directorate of } \\
\text { health }\end{array}$ & $14(2.8 \%)$ \\
\hline Other & $13(2.6 \%)$ \\
\hline $\begin{array}{l}\text { Years of professional experience } \\
\text { (years) }\end{array}$ & $9(1-38)$ \\
\hline \multicolumn{2}{|l|}{ Marital status } \\
\hline Single & $133(26.9 \%)$ \\
\hline Married & $361(73.1 \%)$ \\
\hline \multicolumn{2}{|l|}{ Children } \\
\hline No & $229(46.4 \%)$ \\
\hline Yes & $265(53.6 \%)$ \\
\hline \multicolumn{2}{|l|}{ Chronic disease } \\
\hline No & $360(72,9 \%)$ \\
\hline Yes & $134(27.1 \%)$ \\
\hline
\end{tabular}

Table 2. Participants' who were infected with the COVID-19 and opinions about getting vaccinated against the virus

\begin{tabular}{lll}
\hline Variables & $\mathbf{n}$ & $\mathbf{\%}$ \\
\hline Infection with COVID-19 & & 86.4 \\
Not infected & 427 & 10.7 \\
Recovered during home follow-up & 53 & 1.2 \\
Recovered with inpatient/ward admission & 6 & 0.2 \\
Recovered with inpatient/intensive care admission & 1 & 1.4 \\
Currently being followed up with the diagnosis of the COVID-19 & 7 & 6.3 \\
Intention of getting vaccinated & & 13.2 \\
No intention of getting vaccinated. & 31 & 79.4 \\
Undecided about getting vaccinated. & 65 & 1.2 \\
Intention of getting vaccinated. & 692 & 6 \\
Participated in the phase 3 trials. & 6 & \\
\hline
\end{tabular}


The responses of the participants to the statements in the COVID-19 Vaccination Attitude Scale were compared with the ages, indicating a significantly higher positive attitude score in the group between the ages of 45 and 54 compared to the group between the ages of 25 and 34 ( $\mathrm{p}=$
0.044). According to the assessment of the attitudes of the participants as to the gender variable, positive and negative attitude scores were found to be significantly higher in men than women $(\mathrm{p}=0.011)$ (Table 3).

Table 3. Participants' attitude towards vaccination according to their sociodemographic characteristics

\begin{tabular}{|c|c|c|c|c|c|}
\hline \multirow{2}{*}{ Variables } & \multirow{2}{*}{$\mathbf{n}$} & \multicolumn{2}{|c|}{ Positive Attitude } & \multicolumn{2}{|c|}{ Negative Attitude } \\
\hline & & Mean \pm SD & $\mathbf{p}$ & Mean \pm SD & p \\
\hline \multicolumn{6}{|l|}{ Age (years) } \\
\hline $25-34$ & 249 & $3.68 \pm 0.77^{\mathrm{a}}$ & 0.044 & $3.51 \pm 0.51^{\mathrm{a}}$ & 0.044 \\
\hline $35-44$ & 115 & $3.75 \pm 0.91^{\mathrm{a}, \mathrm{b}}$ & & $3.55 \pm 0.65^{\mathrm{a}, \mathrm{b}}$ & \\
\hline $45-54$ & 105 & $3.95 \pm 0.88^{\mathrm{b}}$ & & $3.71 \pm 0.69^{b}$ & \\
\hline $55-64$ & 25 & $3.62 \pm 1.03^{\mathrm{a}, \mathrm{b}}$ & & $3.52 \pm 0.68^{\mathrm{a}, \mathrm{b}}$ & \\
\hline
\end{tabular}

\begin{tabular}{|c|c|c|c|c|c|}
\hline \multicolumn{6}{|l|}{ Gender } \\
\hline Female & 275 & $3.66 \pm 0.82$ & 0.011 & $3.51 \pm 0.56$ & $\mathbf{0 . 0 3 0}$ \\
\hline Male & 219 & $3.86 \pm 0.87$ & & $3.63 \pm 0.64$ & \\
\hline \multicolumn{6}{|l|}{ Title } \\
\hline Specialist doctor & 118 & $3.78 \pm 0.79$ & 0.079 & $3.61 \pm 0.58$ & 0.108 \\
\hline Family medicine assistant & 146 & $3.62 \pm 0.76$ & & $3.52 \pm 0.51$ & \\
\hline $\begin{array}{l}\text { Non-tenured family physician with ongoing } \\
\text { training for specialty }\end{array}$ & 54 & $4 \pm 0.74$ & & $3.57 \pm 0.59$ & \\
\hline Academic & 20 & $3.84 \pm 1.04$ & & $3.87 \pm 0.56$ & \\
\hline Non-tenured family physician & 156 & $3.75 \pm 0.95$ & & $3.53 \pm 0.68$ & \\
\hline \multicolumn{6}{|l|}{ Place of work } \\
\hline Training and research hospital & 85 & $3.61 \pm 0.85^{\mathrm{a}, \mathrm{b}}$ & $\mathbf{0 . 0 0 3}$ & $3.52 \pm 0.57$ & 0.118 \\
\hline Family health centre & 275 & $3.87 \pm 0.83^{\mathrm{a}}$ & & $3.6 \pm 0.63$ & \\
\hline University hospital & 82 & $3.69 \pm 0.77^{\mathrm{a}, \mathrm{b}}$ & & $3.61 \pm 0.52$ & \\
\hline State hospital & 25 & $3.49 \pm 0.79^{\mathrm{a}, \mathrm{b}}$ & & $3.42 \pm 0.52$ & \\
\hline Provincial/District directorate of health & 14 & $3.59 \pm 0.86^{\mathrm{a}, \mathrm{b}}$ & & $3.29 \pm 0.37$ & \\
\hline Other & 13 & $3.13 \pm 1.2^{\mathrm{b}}$ & & $3.32 \pm 0.66$ & \\
\hline \multicolumn{6}{|l|}{ Marital Status } \\
\hline Single & 133 & $3.54 \pm 0.84$ & $\mathbf{0 . 0 0 1}$ & $3.49 \pm 0.55$ & 0.114 \\
\hline Married & 361 & $3.83 \pm 0.83$ & & $3.59 \pm 0.61$ & \\
\hline \multicolumn{6}{|l|}{ Children } \\
\hline No & 229 & $3.58 \pm 0.82$ & $<0.001$ & $3.46 \pm 0.54$ & $<0.001$ \\
\hline Yes & 265 & $3.89 \pm 0.85$ & & $3.65 \pm 0.63$ & \\
\hline \multicolumn{6}{|l|}{ Chronic Disease } \\
\hline No & 360 & $3.7 \pm 0.84$ & $\mathbf{0 . 0 3 2}$ & $3.53 \pm 0.56$ & 0.067 \\
\hline Yes & 134 & $3.88 \pm 0.86$ & & $3.65 \pm 0.67$ & \\
\hline
\end{tabular}

Student's t test, ANOVA. Different lowercase letters in a column indicate statistically significant difference between groups. 
While $407(82.4 \%)$ of the participants were still actively working in COVID-19-related health care units, 39 (7.9\%) never worked in such facilities during the pandemic. When the participants were evaluated according to whether they work in
COVID-19-related health care facilities, positive and negative attitude scores were found to be significantly higher $(\mathrm{p}=0.024, \mathrm{p}=0.029)$ in the group of physicians that work in a FHC, compared to the group that does not (Table 4).

Table 4. Participants' attitude to the vaccine according to the factors in relation to COVID-19

\begin{tabular}{|c|c|c|c|c|}
\hline & & Positive Attitude & & Negative Attitude \\
\hline Variables & n $(\%)$ & $\begin{array}{c}\text { Mean } \pm \text { SD/ } \\
\text { Median (min-max) }\end{array}$ & $\mathbf{p}$ & $\begin{array}{c}\text { Mean } \pm \text { SD/ } \\
\text { Median (min-max) }\end{array}$ \\
\hline
\end{tabular}

\section{Work in COVID-19-related health} care facilities

$\begin{array}{lcccc}\text { Previously working, not currently } & 48(9.7) & 3.69 \pm 0.87 & 0.209 & 3.54 \pm 0.55 \\ \text { Actively working } & 407(82.4) & 3.78 \pm 0.83 & 3.58 \pm 0.59 \\ \text { Never worked } & 39(7.9) & 3.53 \pm 0.98 & 3.41 \pm 0.69\end{array}$

\section{Work in a FHC for the follow-up of patients with COVID-19}

\begin{tabular}{|c|c|c|c|c|c|}
\hline No & 207(41.9) & $3.65 \pm 0.83$ & 0.024 & $3.5 \pm 0.54$ & 0.029 \\
\hline Yes & $287(58.1)$ & $3.82 \pm 0.85$ & & $3.61 \pm 0.63$ & \\
\hline \multicolumn{6}{|c|}{ Work in a contact tracing team } \\
\hline No & $406(82.2)$ & $3.78 \pm 0.83$ & 0.058 & $3.58 \pm 0.62$ & 0.176 \\
\hline Yes & $88(17.8)$ & $3.59 \pm 0.88$ & & $3.5 \pm 0.49$ & \\
\hline \multicolumn{6}{|c|}{ Work in a sample collection unit } \\
\hline No & $364(73.7)$ & $3.77 \pm 0.86$ & 0.302 & $3.58 \pm 0.63$ & 0.180 \\
\hline Yes & $130(26.3)$ & $3.68 \pm 0.8$ & & $3.51 \pm 0.49$ & \\
\hline \multicolumn{6}{|c|}{ Work in a COVID-19 triage station } \\
\hline No & $370(74.9)$ & $3.77 \pm 0.88$ & 0.370 & $3.56 \pm 0.62$ & 0.785 \\
\hline Yes & $124(25.1)$ & $3.69 \pm 0.75$ & & $3.58 \pm 0.53$ & \\
\hline \multicolumn{6}{|c|}{ Work in a COVID-19 unit } \\
\hline No & $388(78.5)$ & $3.81 \pm 0.85$ & 0.003 & $3.6 \pm 0.61$ & 0.007 \\
\hline Yes & $106(21.5)$ & $3.54 \pm 0.81$ & & $3.42 \pm 0.53$ & \\
\hline \multicolumn{6}{|c|}{ Work in a COVID-19 ICU } \\
\hline No & $465(94.1)$ & $3.77 \pm 0.84$ & 0.032 & $3.57 \pm 0.6$ & 0.185 \\
\hline Yes & $29(5.9)$ & $3.42 \pm 0.83$ & & $3.42 \pm 0.51$ & \\
\hline \multicolumn{6}{|c|}{ Work in a COVID-19 polyclinic } \\
\hline No & $484(98)$ & $3.75 \pm 0.85$ & 0.633 & $3.56 \pm 0.6$ & 0.464 \\
\hline Yes & $10(2)$ & $3.88 \pm 0.76$ & & $3.7 \pm 0.52$ & \\
\hline
\end{tabular}

Student's t test, ANOVA, Mann-Whitney U test.; FHC: Family Health Centre; ICU: Intensive Care Unit

No statistical significance was observed between whether or not participants were infected with the COVID-19 and their positive and negative attitude scores to the vaccine.

The analysis between the sociodemographic characteristics of the participants and their intention to be vaccinated revealed a significant relationship with the years of professional experience. The years of professional experience was found to be significantly higher in the group who was considering getting vaccinated and participated in the Phase 3 Trials compared to the group who did not intend to be vaccinated and were indecisive ( $p$ $<0.001$ ) (Table 5). 
Table 5. Sociodemographic characteristics of the participants according to their intention of getting vaccinated

\begin{tabular}{|c|c|c|c|c|c|}
\hline Variables & No intention & Undecided & $\begin{array}{l}\text { Have the } \\
\text { intention }\end{array}$ & $\begin{array}{l}\text { Participated in } \\
\text { Phase } 3 \text { Trials }\end{array}$ & $\mathbf{p}$ \\
\hline Age (years) & $30(27-56)^{\mathrm{a}}$ & $30(26-57)^{\mathrm{a}}$ & $36(25-63)^{b}$ & $47.5(33-62)^{b}$ & $<0.001$ \\
\hline $25-34$ & $21(67.7)^{\mathrm{a}, \mathrm{b}}$ & $48(73.8)^{\mathrm{a}}$ & $179(45.7)^{\mathrm{b}}$ & $1(16.7)^{b}$ & $<0.001$ \\
\hline $35-44$ & $6(19.4)^{\mathrm{a}}$ & $11(16.9)^{\mathrm{a}}$ & $98(25)^{\mathrm{a}}$ & $0(0)^{\mathrm{a}}$ & \\
\hline $45-54$ & $3(9.7)^{a, b}$ & $4(6.2)^{\mathrm{a}}$ & $94(24)^{\mathrm{b}, \mathrm{c}}$ & $4(66.7)^{\mathrm{c}}$ & \\
\hline $55-64$ & $1(3.2)^{\mathrm{a}}$ & $2(3.1)^{\mathrm{a}}$ & $21(5.4)^{\mathrm{a}}$ & $1(16.7)^{\mathrm{a}}$ & \\
\hline \multicolumn{6}{|l|}{ Gender } \\
\hline Female & $20(64.5)^{\mathrm{a}}$ & $43(66.2)^{\mathrm{a}}$ & $211(53.8)^{\mathrm{a}, \mathrm{b}}$ & $1(16.7)^{\mathrm{b}}$ & 0.044 \\
\hline Male & $11(35.5)^{\mathrm{a}}$ & $22(33.8)^{\mathrm{a}}$ & $181(46.2)^{\mathrm{a}, \mathrm{b}}$ & $5(83.3)^{\mathrm{b}}$ & \\
\hline \multicolumn{6}{|l|}{ Title } \\
\hline Specialist doctor & $5(16.1)^{\mathrm{a}}$ & $13(20)^{\mathrm{a}}$ & $100(25.5)^{\mathrm{a}}$ & $0(0)^{\mathrm{a}}$ & 0.001 \\
\hline Family medicine assistant & $16(51.6)^{\mathrm{a}}$ & $30(46.2)^{\mathrm{a}}$ & $100(25.5)^{\mathrm{b}}$ & $0(0)^{b}$ & \\
\hline Non-tenured family physician & & & & & \\
\hline $\begin{array}{l}\text { with ongoing training for } \\
\text { specialty }\end{array}$ & $1(3.2)^{\mathrm{a}}$ & $7(10.8)^{\mathrm{a}}$ & $45(11.5)^{\mathrm{a}}$ & $1(16.7)^{\mathrm{a}}$ & \\
\hline Academic & $0(0)^{\mathrm{a}}$ & $1(1.5)^{\mathrm{a}}$ & $17(4.3)^{\mathrm{a}}$ & $2(33.3)^{\mathrm{b}}$ & \\
\hline $\begin{array}{l}\text { Non-tenured family medicine } \\
\text { specialist }\end{array}$ & $9(29)^{\mathrm{a}}$ & $14(21.5)^{\mathrm{a}}$ & $130(33.2)^{\mathrm{a}}$ & $3(50)^{\mathrm{a}}$ & \\
\hline \multicolumn{6}{|l|}{ Place of Work } \\
\hline Training and research hospital & $13(41.9)^{\mathrm{a}}$ & $16(24.6)^{\mathrm{a}, \mathrm{b}}$ & $56(14.3)^{\mathrm{b}}$ & $0(0)^{\mathrm{b}}$ & 0.001 \\
\hline Family health centre & $9(29)^{\mathrm{a}}$ & $26(40)^{\mathrm{a}}$ & $237(60.5)^{\mathrm{b}}$ & $3(50)^{a, b}$ & \\
\hline University hospital & $4(12.9)^{\mathrm{a}}$ & $16(24.6)^{\mathrm{a}}$ & $59(15.1)^{a}$ & $3(50)^{\mathrm{a}}$ & \\
\hline State hospital & $2(6.5)^{\mathrm{a}}$ & $4(6.2)^{\mathrm{a}}$ & $19(4.8)^{\mathrm{a}}$ & $0(0)^{\mathrm{a}}$ & \\
\hline $\begin{array}{l}\text { Provincial/District directorate } \\
\text { of health }\end{array}$ & $1(3.2)^{\mathrm{a}}$ & $3(4.6)^{\mathrm{a}}$ & $10(2.6)^{\mathrm{a}}$ & $0(0)^{\mathrm{a}}$ & \\
\hline Other & $2(6.5)^{\mathrm{a}}$ & $0(0)^{\mathrm{a}}$ & $11(2.8)^{\mathrm{a}}$ & $0(0)^{\mathrm{a}}$ & \\
\hline $\begin{array}{l}\text { Years of professional } \\
\text { experience (years) }\end{array}$ & $5(3-33)^{\mathrm{a}}$ & $5(2-34)^{\mathrm{a}}$ & $10(1-38)^{b}$ & $22.5(10-34)^{\mathrm{c}}$ & $<0.001$ \\
\hline \multicolumn{6}{|l|}{ Marital status } \\
\hline Single & $13(41.9)^{\mathrm{a}}$ & $24(36.9)^{\mathrm{a}}$ & $96(24.5)^{\mathrm{a}, \mathrm{b}}$ & $0(0)^{b}$ & 0.016 \\
\hline Married & $18(58.1)^{\mathrm{a}}$ & $41(63.1)^{\mathrm{a}}$ & $296(75.5)^{\mathrm{a}, \mathrm{b}}$ & $6(100)^{\mathrm{b}}$ & \\
\hline \multicolumn{6}{|l|}{ Children } \\
\hline No & $21(67.7)^{\mathrm{a}}$ & $36(55.4)^{\mathrm{a}}$ & $171(43.6)^{\mathrm{a}, \mathrm{b}}$ & $1(16.7)^{\mathrm{b}}$ & 0.010 \\
\hline Yes & $10(32.3)^{\mathrm{a}}$ & $29(44.6)^{\mathrm{a}}$ & $221(56.4)^{\mathrm{a}, \mathrm{b}}$ & $5(83.3)^{\mathrm{b}}$ & \\
\hline
\end{tabular}

The results are shown as median (min-max) or $\mathrm{n}(\%)$. Kruskal-Wallis test, Fisher's Exact test. Different lowercase letters in a row indicate statistically significance significant difference between groups.

The mean scores corresponding to the expressions evaluating the positive and negative attitudes of the participants are shown in Table 6 .

In the evaluation of the selected subgroups according to the participants' intention of being vaccinated (the group that was vaccinated upon participating in Phase 3 Trials was not included in that evaluation), positive and negative attitude subscores were found to be the lowest in the group who did not intend to be vaccinated (Table 7).

Table 6. Mean Scores in the Scale and Reliability Coefficients of the Participants

\begin{tabular}{|c|c|c|c|c|c|}
\hline & Mean & SD & Min & Max & $\begin{array}{l}\text { Cronbach's } \\
\text { alpha }\end{array}$ \\
\hline Positive Attitude & 3.7 & 0.8 & 1 & 5 & 0.894 \\
\hline I want my family to have the vaccine to be developed for this disease. & 3.9 & 0.9 & 1 & 5 & - \\
\hline $\begin{array}{l}\text { I want to have the vaccine to be developed for this disease as much as } \\
\text { possible. }\end{array}$ & 3.9 & 1 & 1 & 5 & - \\
\hline I think everybody should have the vaccine to be developed for this disease. & 3.9 & 1 & 1 & 5 & - \\
\hline I trust to explanations made for the vaccine to be developed/developed. & 3.2 & 0.9 & 1 & 5 & - \\
\hline Negative Attitude & 3.6 & 0.6 & 1.4 & 5 & 0.693 \\
\hline The vaccine to be developed/developed may cause the spread of the virus. & 3.9 & 0.9 & 1 & 5 & - \\
\hline $\begin{array}{l}\text { I think the vaccine to be developed/developed will not/does not have a } \\
\text { protective effect. }\end{array}$ & 3.7 & 0.8 & 1 & 5 & - \\
\hline The vaccine to be developed/developed is dangerous. & 4 & 0.7 & 1 & 5 & - \\
\hline $\begin{array}{l}\text { I think the effectiveness of the vaccine to be developed/developed will not } \\
\text { be/has not been tested adequately. }\end{array}$ & 2.7 & 1 & 1 & 5 & - \\
\hline I think I may survive the epidemic without a vaccine. & 3.6 & 1 & 1 & 5 & - \\
\hline
\end{tabular}


Table 7. Scale Scores According to Participants' Intention of Getting Vaccinated.

\begin{tabular}{|c|c|c|c|c|c|c|c|c|c|c|}
\hline \multirow[b]{2}{*}{ Scale Scores } & \multicolumn{3}{|c|}{ No intention } & \multicolumn{3}{|c|}{ Undecided } & \multicolumn{3}{|c|}{ Have the intention } & \multirow[b]{2}{*}{$\mathbf{p}$} \\
\hline & $\begin{array}{l}\text { Mean } \pm \\
\text { SD }\end{array}$ & Min & Max & $\begin{array}{l}\text { Mean } \pm \\
\text { SD }\end{array}$ & Min & Max & $\begin{array}{l}\text { Mean } \pm \\
\text { SD }\end{array}$ & Min & Max & \\
\hline Positive Attitude Score & $2.8 \pm 1.1^{\mathrm{a}}$ & 1 & 5 & $2.9 \pm 0.5^{\mathrm{a}}$ & 1 & 3.8 & $4 \pm 0.7^{b}$ & 1.8 & 5 & $<0.001$ \\
\hline $\begin{array}{l}\text { I want my family to have the vaccine to } \\
\text { be developed for this disease. }\end{array}$ & $2.9 \pm 1.3^{\mathrm{a}}$ & 1 & 5 & $3 \pm 0.6^{\mathrm{a}}$ & 1 & 4 & $4.1 \pm 0.8^{\mathrm{b}}$ & 1 & 5 & $<0.001$ \\
\hline $\begin{array}{l}\text { I want to have the vaccine to be } \\
\text { developed for this disease as much as } \\
\text { possible. }\end{array}$ & $2.5 \pm 1.2^{\mathrm{a}}$ & 1 & 5 & $3 \pm 0.6^{\mathrm{b}}$ & 1 & 4 & $4.1 \pm 0.9^{c}$ & 1 & 5 & $<0.001$ \\
\hline $\begin{array}{l}\text { I think everybody should have the } \\
\text { vaccine to be developed for this disease. }\end{array}$ & $3 \pm 1.3^{\mathrm{a}}$ & 1 & 5 & $3 \pm 0.7^{\mathrm{a}}$ & 1 & 4 & $4.2 \pm 0.8^{\mathrm{b}}$ & 1 & 5 & $<0.001$ \\
\hline $\begin{array}{l}\text { I trust to explanations made for the } \\
\text { vaccine to be developed/developed. }\end{array}$ & $2.6 \pm 1.1^{\mathrm{a}}$ & 1 & 5 & $2.6 \pm 0.8^{\mathrm{a}}$ & 1 & 5 & $3.4 \pm 0.9^{b}$ & 1 & 5 & $<0.001$ \\
\hline Negative Attitude Score & $2.9 \pm 0.7^{\mathrm{a}}$ & 1.4 & 4.8 & $3.1 \pm 0.4^{\mathrm{a}}$ & 2.4 & 4.2 & $3.7 \pm 0.5^{\mathrm{b}}$ & 2.4 & 5 & $<0.001$ \\
\hline $\begin{array}{l}\text { The vaccine to be developed/developed } \\
\text { may cause the spread of the virus. }\end{array}$ & $3.5 \pm 1^{\mathrm{a}}$ & 1 & 5 & $3.6 \pm 0.8^{a}$ & 2 & 5 & $4 \pm 0.9^{b}$ & 1 & 5 & 0.001 \\
\hline $\begin{array}{l}\text { I think the vaccine to be } \\
\text { developed/developed will not/does not } \\
\text { have a protective effect. }\end{array}$ & $3.1 \pm 1^{\mathrm{a}}$ & 1 & 5 & $3.2 \pm 0.7^{\mathrm{a}}$ & 2 & 5 & $3.8 \pm 0.8^{\mathrm{b}}$ & 1 & 5 & $<0.001$ \\
\hline $\begin{array}{l}\text { The vaccine to be developed/developed } \\
\text { is dangerous. }\end{array}$ & $3.4 \pm 1^{\mathrm{a}}$ & 1 & 5 & $3.5 \pm 0.6^{\mathrm{a}}$ & 3 & 5 & $4.1 \pm 0.7^{b}$ & 2 & 5 & $<0.001$ \\
\hline $\begin{array}{l}\text { I think the effectiveness of the vaccine } \\
\text { to be developed/developed will not } \\
\text { be/has not been tested adequately. }\end{array}$ & $2 \pm 0.9^{\mathrm{a}}$ & 1 & 5 & $2.1 \pm 0.8^{\mathrm{a}}$ & 1 & 4 & $2.8 \pm 1^{\mathrm{b}}$ & 1 & 5 & $<0.001$ \\
\hline $\begin{array}{l}\text { I think I may survive the epidemic } \\
\text { without a vaccine. }\end{array}$ & $2.6 \pm 1^{\mathrm{a}}$ & 1 & 5 & $3.3 \pm 0.9^{b}$ & 2 & 5 & $3.7 \pm 0.9^{c}$ & 1 & 5 & $<0.001$ \\
\hline
\end{tabular}

\section{DISCUSSION}

The present study conducted with family physicians in Turkey found that the necessity to provide everyone with the COVID-19 vaccine is the very statement indicating the highest positive attitude, while the statement about the reliance on explanations for the vaccine turned out the least positive attitude. The most obvious negative attitude in our study is related to the efficacy of the vaccine with the concern that it has not yet been adequately tested. An important finding in our study is the fact that $67(13.6 \%)$ of the participants were diagnosed with COVID-19 during the pandemic, although almost all of the participants were working in COVID-19-related units with a total of $455(92.1 \%)$ physicians. This fact indicates that family physicians are successfully practicing the duty of preventive medicine for themselves and the society. There are many studies in the literature on the COVID-19 pandemic and issues related to vaccination. The present study, however, assumed the likelihood of a direct influence that may be caused by the attitudes and behaviour of family physicians in Turkey towards a vaccine on the COVID-19 vaccine immunization rates, and study groups were limited to only family physicians, which is the strength of our study.

Various studies have shown that the vaccine adoption in the society decreases, while its opposition increases day by day (11-13). For example, a study investigating the relationship between the prevalence of vaccine rejection and demographic characteristics and underlying reasons showed that $6.57 \%$ of the participants considered vaccines useless. In the same study, the rate of those who considered vaccines useless was found to be statistically significantly higher in women than men, and in those with a higher education level than those with lower education (13).

A multi-centre study investigating the knowledge and attitudes of 250 family physicians from eight countries about COVID-19 between March and April 2020, in a period that could be considered as the beginning of the pandemic, reported that $105(42 \%)$ participants wanted to volunteer in COVID-19 vaccine studies, and in like manner, $68(27 \%)$ participants stated that they could encourage family members or friends to volunteer (14). In our study, the number of family physicians who voluntarily participated in the Phase 3 Trials of the COVID-19 vaccine was only 6 $(1.2 \%)$, yet the mean positive attitude score of the participants in relation to their willingness for family members' getting the COVID-19 vaccine was found to be high in all participants with the score of $3.9 \pm 0.9$.

In a study conducted to investigate the vaccine-hesitant attitudes regarding the COVID-19 in Turkish and British societies, $31 \%$ of the participants in Turkey and $14 \%$ of them in the UK were found hesitant about getting vaccinated. Furthermore, $3 \%$ of the participants in each country refused to be vaccinated, while the vaccination rate was reported to be higher in men compared to women in Turkey with respect to agreeing to get the COVID-19. The present study has pointed out, in particular, the level of hesitance in Turkey, and suggested that sharing new virus-related scientific data more with the general public may help prevent hesitance (15). Of all the participants in our study, $31(6.3 \%)$ stated that they had no intention of getting vaccinated, while $65(13.2 \%)$ participants stated that they were undecided about getting 
vaccinated. In parallel with the above-mentioned study, positive and negative attitude scores of men in our study were found to be significantly higher than those of women. Physicians from only 53 out of 81 provinces in Turkey participated in our study and all provinces could not be contacted for the data collection stage, which is one of the limitations of our study. Another limitation is that the density of the number of participants differed according to the provinces.

In a study conducted in a period when there was no COVID-19 vaccine yet approved in Israel, hesitations about the COVID-19 vaccine in healthcare workers and the general population were evaluated, and $78 \%$ of doctors reported that they wanted to have the COVID-19 vaccine when available (16). Similarly, in our study, 392 (79.4\%) family physicians stated that they had the intention of getting vaccinated, but that the vaccine had not yet been delivered to the unit where they work. In addition, the mean score of positive attitudes of family physicians towards getting the vaccine developed against the virus as soon as possible was found to be high, with the score of $3.9 \pm 1$. In the same study, the biggest concern for both doctors and the general population appeared to be the fear of safety of the vaccine, while the highest concern was reported to be related to quality control (16). In our study, the negative attitude mean score of 31 $(6.27 \%)$ family physicians who had no intention of getting vaccinated was $2.9 \pm 0.7$, while the most significant negative attitude in the same group was that the efficacy of the vaccine was not adequately tested with the given score of $2 \pm 0.9$.
In a study conducted with 123 family physicians and interns in Malta, Grech et al., found that $70.8 \%$ of family physicians and $29.6 \%$ of interns were willing to get the COVID-19 vaccine. The analysis of the willingness to be vaccinated according to age groups indicated that the lowest rate was between the ages of $35-44$ with $41.7 \%$, while the highest rates were found between the ages of 55-64 with $80.6 \%$ and over the age of 65 with $100 \%$. The same study pointed out that most of the concerns about the COVID-19 vaccine were due to the inadequate information on the new vaccines and the possible, unknown long-term side effects (17). In our study, the willingness of family physicians to get vaccinated was found to be $80.6 \%$ higher than that found in the study of Grech et al, with the volunteers participating in the Phase 3 Trials. In addition, the examination of the attitudes towards COVID-19 vaccine in our study showed that the highest positive attitude appeared in the 45-54 age group, while the highest negative attitude was observed in the 25-34 age group.

\section{CONCLUSION}

It is believed that the hesitant and unsafe attitude of family physicians towards vaccination will negatively affect the vaccination rates in the society. In this regard, in order to achieve the desired protective effect, it is necessary to inform family physicians about the efficacy and benefits of the vaccine and to convey this information to individuals through family physicians so that the vaccine adoption will increase across the society, and the desired levels can be reached in terms of vaccination rates.

\section{REFERENCES}

1. Gao Y, Yan L, Huang Y, Liu F, Zhao Y et al. Structure of the RNA-dependent RNA polymerase from COVID-19 virus. Science. 2020;368(6492):779-782.

2. van Riel D, de Wit E. Next-generation vaccine platforms for COVID-19. Nat Mater. 2020;19(8):810-812.

3. Burki TK. The Russian vaccine for COVID-19. Lancet Respir Med. 2020;8(11):e85-e86.

4. World Health Organization. COVID-19 vaccine tracker and landscape [Internet]. [cited 2021 Jul 8]. Available from: https://www.who.int/publications/m/item/draft-landscape-of-covid-19-candidate-vaccines

5. Krause PR, Fleming TR, Longini IM, Peto R, Beral V, Bhargava B, et al. Placebo-Controlled Trials of Covid-19 Vaccines-Why We Still Need Them. N Engl J Med. 2021;384(2):e2.

6. Krause P, Fleming TR, Longini I, Henao-Restrepo AM, Peto R, Dean R, et al. COVID-19 vaccine trials should seek worthwhile efficacy. Lancet. 2020;396(10253):741-743.

7. Hekimoğlu $\mathrm{CH}$. Vaccine epidemiology: Epidemiologic measures of the effects of a vaccine and vaccination. Turkish Bulletin of Hygiene \& Experimental Biology. 2016;73(1):55-70.

8. Lee JQ, Loke $\mathrm{W}, \mathrm{Ng}$ QX. The role of family physicians in a pandemic: a blueprint. Healthcare (Basel). 2020;8(3):198.

9. Kalkınma Bakanlığı Sağlık Hizmet Kalitesi Ve Mali Sürdürülebilirlik - Özel İhtisas Komisyonu Raporu 2018;22. [Internet]. [cited 2020 Dec 15]. Available from: https://www.sbb.gov.tr/wpcontent/uploads/2020/04/SaglikHizmetKalitesi_ve_MaliSurdurulebilirlikOzelIhtisasKomisyonuRaporu.pdf

10. Geniş B, Gürhan N, Koç M, Geniş Ç, Şirin B, Çırakoğlu OC, et al. Development of Perception and Attitude Scales Related with COVID-19 Pandemia. Pearson Journal of Social Sciences - Humanities. 2020;5(7):306-328.

11. Zaidi MB, Flores-Romo L. The growing threat of vaccine resistance: a global crisis. Current Treatment Options in Infectious Diseases. 2020;12, 122-134.

12. Lahouati M, De Coucy A, Sarlangue J, Cazanave C. Spread of vaccine hesitancy in France: What about YouTube ${ }^{\mathrm{TM}}$ ? Vaccine. 2020;38(36):5779-5782. 
13. Özceylan G, Toprak D, Esen ES. Vaccine rejection and hesitation in Turkey, Hum Vaccin Immunother. 2020;16(5):1034-1039.

14. Gökdemir Ö, Pak H, Bakola M, Bhattacharya S, Hoedebecke K, Jelastopulu E. Family Physicians' Knowledge about and Attitudes towards COVID-19 - A Cross-sectional Multicentric Study. Infect Chemother. 2020;52(4):539-549.

15. Salali GD, Uysal MS. COVID-19 vaccine hesitancy is associated with beliefs on the origin of the novel coronavirus in the UK and Turkey. Psychol Med. 2020;1-3.

16. Dror AA, Eisenbach N, Taiber S, Morozov NG, Mizrachi M, Zigron A, et al. Vaccine hesitancy: the next challenge in the fight against COVID-19. Eur J Epidemiol. 2020;35(8):775-779.

17. Grech V, Bonnici J, Zammit D. Vaccine hesitancy in Maltese family physicians and their trainees vis-a-vis influenza and novel COVID-19 vaccination. Early Hum Dev. 2020;105259. 